\title{
TOLERANCE AND CROSS TOLERANCE TO TOXIC EFFECTS OF MORPHINE, METHADONE AND I-ALPHA-ACETYLMETHADOL (LAAM) IN NAIVE AND MORPHINE DEPENDENT RATS
}

\author{
Sukehiro CHIBA², Edward J. MORETON and Naim KHAZAN \\ Department of Pharmacology and Toxicology, University of Maryland \\ School of Pharmacy, Baltimore, Maryland 21201, U.S.A.
}

Accepted January 30, 1978

Methadone has been used in maintenance program for the treatment of heroin addiction (1). More recently, and in accordance with data from clinical experimentation (2) levomethadyl acetate ( -alpha-acetylmethadol [LAAM]) is being used clinically as a substitute for methadone in the treatment of heroin addicts. Experimental data on the development of tolerance and cross tolerance to these narcotics are few. Toxic signs following massive doses of morphine, methadone, and LAAM have been reported to include convulsion, respiratory depression, apnea, cyanosis, and coma (3-4). Formerly, it was considered that with chronic administration of morphine or methadone, tolerance develops only to the depressant effects such as respiratory depression, analgesia, and hypnosis (5). However, recent studies have demonstrated the development of tolerance to the stimulatory or convulsant effects (6-7). The purpose of this study was to compare the toxic effects of morphine, methadonc, and LAAM in naive and morphine-dependent rats with regard to tolerance and cross tolerance to the respiratory depressant and the convulsant effects of these narcotics.

Adult female Sprague-Dawley rats, weighing 200 to $250 \mathrm{~g}$, were made dependent on morphine by a series of injections beginning at a dose of $10 \mathrm{mg} / \mathrm{kg}$ given i.p. three times daily, followed by $20,50,100$, and $200 \mathrm{mg} / \mathrm{kg}$ three times daily on successive days. On the seventh day, $200 \mathrm{mg} / \mathrm{kg}$ of morphine was administered one to two hours prior to testing. In the first experiment, control rats $(n=14)$ and morphine-dependent rats $(n=10)$ were intravenously infused with a $5.0 \%$ morphine sulfate solution at a rate of $1.0 \mathrm{ml} / \mathrm{min}$ using the technique of Orloff et al. (8). Infusions were stopped when either convulsant activity or severe respiratory depression was evident.

Morphine i.v. infusions in the control group produced clonic-tonic convulsions in six rats, twitching followed by clonic-tonic convulsions in four rats, and severe respiratory depression with no convulsions in four rats. The mean dose of morphine 1 standard error of the mean that induced convulsions was $317.3 \pm 8.2 \mathrm{mg} / \mathrm{kg}$. In the morphine-dependent group, i.v. morphine infusions at a mean dose of $238.4 \pm 9.2 \mathrm{mg} / \mathrm{kg}$ produced twitching followed by clonic-tonic convulsions in all rats. These findings suggest that the severe respiratory depression induced by morphine in the control group caused a reduction in

1 This research was supported by NIDA Grant No. DA01050

2 Present address: Drug Safety Research Centre, Central Research Division, Takeda Chemical Industries, Ltd., Takatsuki, Osaka 569, Japan 
convulsive reactivity. In line with this suggestion, Gellhorn and Ballin (9) proposed that severe anoxia preceding the dysfunction of the cortex and brain stem reduced the susceptibility to electroshock-induced convulsing in rats.

In the sccond expcriment, the degree to which naloxone could counteract the respiratory dcpressant effect of morphine without blocking the convulsant effect was determined. Three control groups of rats ( $\mathrm{n}=10 /$ group) were pretreated with $0.5,1.0$, and $2.0 \mathrm{mg} / \mathrm{kg}$ of naloxone hydrochloride i.p. 20 min prior to morphine infusions. Likewise, one morphinedependent group $(n=10)$ was pretreated with $1.0 \mathrm{mg} / \mathrm{kg}$ i.p. of naloxone prior to morphine infusion.

Naloxone pretreatment affected the mean dose of morphine which produced convulsion. The mean doses of morphine for the control groups given $0.5,1.0$, and $2.0 \mathrm{mg} / \mathrm{kg}$ of naloxone were $306.5+9.2,265.9 \pm 10.1$, and $435.9-29.7 \mathrm{mg} / \mathrm{kg}$, respectively. The i.v. infusion of morphine into morphine-dependent rats produced twitching followed by clonic-tonic convulsions with a mean dose of $417.2 \pm 12.7 \mathrm{mg} / \mathrm{kg}$. This mean is significantly different (Student's t-test: $t=8.61, \mathrm{df}=18, \mathrm{P}<0.01)$ from the mean convulsant dose $(265.9 \pm 10.1)$ of morphine for the control group pretreated with $1.0 \mathrm{mg} / \mathrm{kg}$ of naloxone. These findings suggest that the naloxone treatment counteracted the respiratory depressant effect of morphine and increased the susceptibility to morphine-induced convulsion in the control rats pretreated with $1.0 \mathrm{mg} / \mathrm{kg}$ of naloxone. It may have also partially antagonized the convulsive effect of morphine in the morphine-dependent rats that developed tolerance to the respiratory depression, as suggested previously by Chapman and Walaszek (10), Fiut et al. (11) and Gilbert and Martin (12). Thus, when the respiratory effect of morphine was blocked by naloxone, tolerance to the convulsant effect of morphine was demonstrated.

In the third experiment, one control group $(n=10)$ and one morphine-dependent group $(\mathrm{n}=10)$ were infused with a $0.5 \%$ methadone hydrochloride solution at a rate of $0.5 \mathrm{ml} / \mathrm{min}$. Infusions were stopped when either convulsant activity or severe respiratory depression was evident.

Methadone, unlike morphine, induced tonic-clonic convulsions in all control rats without naloxone pretreatment. Methadone also induced twitching followed by tonicclonic convulsions in all morphine-dependent rats. The mean convulsant doses of methadone for the control and morphine-dependent rats were $12.2 \pm 0.3$ and $21.7+1.2 \mathrm{mg} / \mathrm{kg}$, respectively. The difference between these two means is significant $(\mathrm{t}=12.15, \mathrm{df}=18$, $\mathrm{P}<0.01$ ), demonstrating cross-tolerance to methadone-induced convulsions in morphinedependent rats.

In the fourth experiment, three control groups ( $\mathrm{n}=6 /$ /group) were given i.p. injections of 50,75 , and $100 \mathrm{mg} / \mathrm{kg}$ of LAAM hydrochloride, respectively. The number of rats that convulsed as well as the latencies to the onset of any convulsing, were determined. The dose of LAAM producing convulsions in $50 \%$ of the rats (CD50) was calculated by the method of Litchfield and Wilcoxon (13). Three morphine-dependent groups ( $n=6 /$ group) were treated in a similar manner to study possible development of cross-tolerance to LAAM.

The CD50 values for LAAM and the latencies to onset of clonic convulsions were 
TABLE 1. Mean latencies to onset of convulsion and of gasping after LAMM administration and $50 \%$ convulsant dose (CD 50) of LAAM

\begin{tabular}{|c|c|c|c|c|}
\hline \multirow{3}{*}{$\begin{array}{l}\text { Dose } \\
\text { mg/kg } \\
\text { i.p. }\end{array}$} & \multicolumn{4}{|c|}{ Mean Latency (min) to Onset of } \\
\hline & \multicolumn{2}{|c|}{ Convulsion } & \multicolumn{2}{|c|}{ Gasping } \\
\hline & Control & $\begin{array}{l}\text { Morphine- } \\
\text { dependent }\end{array}$ & Control & $\begin{array}{l}\text { Morphine- } \\
\text { dependent }\end{array}$ \\
\hline 50 & $\begin{array}{c}\text { none } \\
(n=0 / 6)\end{array}$ & $\begin{array}{c}\text { none } \\
(n=0 ; 6)\end{array}$ & $\begin{array}{c}71.7+8.5 \\
(\mathrm{n}=6,6)\end{array}$ & $\begin{array}{c}\text { none } \\
(n=0 / 6)\end{array}$ \\
\hline 75 & $\begin{array}{c}24.0+11.8^{h} \\
(n=3 / 6)\end{array}$ & $\begin{array}{c}23.5+1.5 \\
(n=2 / 6)\end{array}$ & $\begin{array}{c}64.2 \pm 16.3 \\
(\mathrm{n}=4 / 6)\end{array}$ & $\begin{array}{c}\text { none } \\
(n=0 / 6)\end{array}$ \\
\hline 100 & $\begin{array}{l}9.2-5.9 \\
(n=5 / 6)\end{array}$ & $\begin{array}{c}11.8 \pm 1.8 \\
(n=5,6)\end{array}$ & $\begin{array}{c}53 \\
(n=1 / 6)\end{array}$ & $\begin{array}{c}\text { none } \\
(n=0 / 6)\end{array}$ \\
\hline $\begin{array}{l}\mathrm{CD} 50 \\
\mathrm{mg} / \mathrm{kg}\end{array}$ & $\begin{array}{c}83.2 \\
(75.8-90.9)^{n}\end{array}$ & $\begin{array}{l}85.1 \\
(77.6-93.1)\end{array}$ & & \\
\hline
\end{tabular}

$a: n=$ Number of convulsed or gasped rats/number of treated rats. b: Mean SE. c: $95 \%$ confidence limits.

similar for control and morphine-dependent rats (Table 1). After convulsions in 7 of 8 control rats and 3 of 7 morphine-dependent rats, these animals died. On the other hand, almost all control rats, which survived convulsions or did not have convulsions, died of respiratory depression within one to five hours after the i.p. administration of LAAM, in contrast to morphine-dependent rats which showed no signs of any respiratory effects. These results demonstrate the development of cross-tolerance to LAAM-induced respiratory depression in morphine-dependent rats, but no cross-tolerance to its convulsant effect was detected.

Our observations indicate that the differential degree of toxicity to the three narcotics seen in the naive and in morphine-dependent rats used herein may throw some light on the toxic aspects involved in narcotic dependence in humans.

Acknowledgenent: We are indebted to Dr. T. Yanagita for pertinent advice.

\section{REFERENCES}

1) JAFFE, J.H. AND SFNAY, E.C.: Methadone and 1-methadyl acetate: Use in management of narcotic addiction. $J$. Am. med. Assoc. 216, 1303-1305 (1971); 2) Levine, R., Zaks, A., Fink, M. AND FREFDMAN, A.M.: Levomethadyl acetate, prolonged duration of opioid effects, including cross tolerance to heroin, in man. J. Am. med. Asroc. 226, 316-318 (1973); 3) Finnegan, J.K., HaAG, H.B., Larson, P.S. AND Dreyfuss, M.L.: Observations on the comparative pharmacologic actions of 6-dimethylamino-4,4-diphenyl-3-heptanone (amidone) and morphine. $J$. Pharmacol. exp. Ther. 92, 269-276 (1948); 4) VEATCH, R.M., AdLeR, T.K. AND WAY, E.L.: The importance of steric configuration in certain morphine-mimetic actions of synthetic analgetics. J. Pharmacol. exp. Ther. 145, 11-19 (1964); 5) SfFvers, M.H. and DeNeau, G.A.: Physiological aspects of tolerance and physical dependence. Physiological Pharmacology, Edited by Root, W.S. ANo Hoffman, F.G., Vol. 1, p. 565.640 Academic Press, New York (1963); 6) Goldstein, A. ANd Suleftas, P.: Tolerance to opioid narcotics. 1. Tolerance to the "running fit" caused by levorphanol in the mouse. J. Pharmacol. exp. Ther. 169, 175-184 (1969); 7) Mannino, R.A. And Wolf, H.H.: Opiate receptor phenomenon: Proconvulsant action of morphine in the mouse. Life Sci. 13, 2097-2108 (1973); 8) Orloff, M.J., Williams, H.L. A.jo Pfeiffer, C.C.: Timed intravenous 
infusion of metrazol and strychnine for testing anticonvulsant drugs. Proc. Soc. exp. Biol. Med. 70, 254-257 (1949); 9) Gellhorn, E. ANd Ballin, H.M.: Further investigations on effect of anoxia on convulsions. Am. J. Physiol. 162, 503-506(1950); 10) Chapman, J.E. AND Walaszek, E.J.: Antagonism of some toxic effects of dextropropoxyphene by nalorphine. Toxicol. appl. Pharmacol. 4, 752-758 (1962); 11) Fiut, R.E., PICchiont, A.L. And ChIN, L.: Antagonism of convulsive and lethal effects induced by propoxyphene. J. Pharm. Sci. 55, 1085-1087 (1966): 12) Gilbert, P.E. AND MARTin, W.R.: Antagonism of the convulsant effects of heroin, d-propoxyphene, meperidine, normeperidine and thebaine by naloxone in mice. J. Pharmacol. exp. Ther. 192, 538-541 (1975); 13) LitChfield, J.T. AND Wilcoxon, F.J.: A simplified method of evaluating dose-effect experiments. J. Pharmacol. exp. Ther. 96, 99-106 (1946)

\title{
INFLUENCES OF SODIUM, OUABAIN AND TRICYCLIC ANTIDEPRESSANT DRUGS ON L-[ $\left.{ }^{3} \mathrm{H}\right]$ NOREPINEPHRINE UPTAKE INTO SYNAPTOSOMAL FRACTIONS OF DEVELOPING RAT BRAIN
}

\author{
Yasuyuki NOMURA, Yasue TANAKA and Tomio SEGAWA \\ Department of Pharmacology, Institute of Pharmaceutical Sciences, \\ Hiroshima University School of Medicine, Kasumi 1-2-3, Hiroshima 734, Japan
}

Accepted February 15, 1978

The central noradrenergic neuron has a high affinity uptake mechanism of $\mathrm{L}-\left[{ }^{3} \mathrm{H}\right]$ norepinephrine $\left(\mathrm{L}-\left[{ }^{3} \mathrm{H}\right] \mathrm{NE}\right)$ which is saturable, sodium dependent and ouabain sensitive (1-3). The high affinity uptake mechanism of $\mathrm{L}-\left[{ }^{3} \mathrm{H}\right] \mathrm{NE}$ appears first at 18 days of gestation in the rat brain $(4,5)$. Although the innervation of both noradrenergic and serotonergic neurons progress in the rat brain with increasing age, no developmental difference in affinity of $\mathrm{L}-\left[{ }^{3} \mathrm{H}\right] \mathrm{NE}$ and $\left[{ }^{3} \mathrm{H}\right] 5$-hydroxytryptamine $\left(\left[{ }^{3} \mathrm{H}\right] 5-\mathrm{HT}\right)$ to brain synaptosomes has been demonstrated $(4,5,6,7)$. With regard to the high affinity $\left[{ }^{3} \mathrm{H}\right] 5$-HT uptake system, sodium dependence was lower in the neonatal synaptosomes than in the adult (6). On the other hand, two antidepressant drugs, desmethylimipramine (DMI) and imipramine (IM) did not show significant difference in those inhibitory potencies on [3 $\left.{ }^{3} \mathrm{H}\right] 5-\mathrm{HT}$ uptake at any developmental stage, suggesting that $\left[{ }^{3} \mathrm{H}\right] 5-\mathrm{HT}$ uptake might be specific for 5-HT neuron also in the neonatal brain $(6)$.

To gain insight into the sodium dependence and specificity of the high affinity $L-\left[{ }^{3} \mathrm{H}\right] \mathrm{NE}$ transport mechanism in the neonatal brain, we investigated the influence of sodium, ouabain, DMI and IM on the L- $\left[{ }^{3} \mathrm{H}\right] N E$ uptake into synaptosomal fractions of the developing rat brain.

The uptake experiment was carried out by the method previously reported (6). Wistar rats of both sexes and at various ages were sacrificed by cervical decapitation and the brain was homogenized in 9 vol. of ice-cold $0.32 \mathrm{M}$ sucrose bubbled with $95 \% \mathrm{O}_{2}-5 \% \mathrm{CO}_{2}$ for 10 min using a Teflon pestle. The crude mitochondrial $P_{2}$ fraction prepared by the technique 